ISSN 1817-3721, E-ISSN 1818-8745

Plant Tissue Cult. \& Biotech. 28(2): 161-169, 2018 (December)

CBangladesh Assoc. for Plant Tissue Culture \& Biotechnology

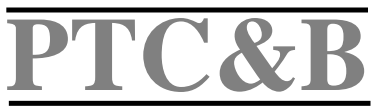

\title{
In vitro Mass Propagation from Shoot Tip of Dendrobium Red Bull - An Endangered Epiphytic Orchid
}

\author{
A. A. Mamun*, M. M. Islam, M. Ahmed and G. C. Ghosh \\ Agrotechnology Discipline, Khulna University, Khulna-9208, Bangladesh \\ Key words: Dendrobium, Growth regulators, In vitro micropropagation, Ex vitro \\ survivability
}

\begin{abstract}
An experiment was carried out to optimize the doses and combinations of growth regulators for in vitro propagation of Dendrobium Red Bull through shoot tip culture. The experiment was laid out according to completely randomized design with 15 treatments and three replications. For multiple shoot induction, newly grown shoot buds (keikies) were cultured on MS supplemented with various combinations of NAA and BAP. The regenerated plants were transferred to ex vitro in different substrates and acclimatized. Best response for the shoot length $(21.19 \mathrm{~mm})$ was obtained from the medium supplemented with $3.0 \mathrm{mg} / \mathrm{l} \mathrm{BAP}$ with $1.5 \mathrm{mg} / \mathrm{l}$ NAA. Similarly maximum number of leaves was observed from the same combination at all the recorded days except 60 days, whereas the maximum shoot number (7.66) was obtained from the medium containing 3.0 $\mathrm{mg} / \mathrm{l} \mathrm{BAP}+1.0 \mathrm{mg} / \mathrm{l} \mathrm{NAA}$. The shoots were then transferred to root inducing medium and well rooted plants were transferred to different substrates. Survivability of the regenerated plants varied from 60 to $92 \%$. The substrate containing cocodust showed maximum survivability (92\%) whereas minimum $(60 \%)$ was observed from the substrate containing course sand. BAP and NAA proved to be good growth regulators for in vitro multiplication of Dendrobium.
\end{abstract}

\section{Introduction}

Orchid constitutes an order of royalty in the world of ornamental plants. The Dendrobium is the second genus of Orchidaceae, which is composed of approximately 1500 species scattered in the world, and only a few of these are used as ornamentals (Chen and Ji 1998). Dendrobium Red Bull is one of the socalled jewel orchids, which are planted originally for its beautiful flower. It

*Author for correspondence: <mamungpbat@ku.ac.bd>. DOI: https://doi.org/10.3329/ptcb.v28i2.39675 
could be used as medicine against digestive, respiratory and ophthalmic diseases (Chen and Guo 2003). But nowadays this orchid is facing the threat of extinction owing to over collection from natural resources (Zhang et al. 2000). Orchid requires a combination of different factors for reproduction in nature. The propagation of this species through sexual means is a very slow process as its seeds lack endosperm and need fungal stimulant for germination in nature (Arditti et al. 1982 ). In nature, only 2 to $5 \%$ of seeds germinate (Rao 1997) even if they do so, the seeds take a long time for their germination and any disturbance in the habitat or physical environment destroys the whole population. Orchids are highly heterozygous and their vegetative propagation through division of clumps of rhizomes, bulbs or by the rooting of offshoots also takes long time and difficult to obtain desired number of plants. This difficulty in natural population drives the Dendrobium Red Bull to extinction. It is therefore important to take initiative for the mass propagation of this orchid and establish it in nature. Thus, tissue culture technique is a potential alternative method for mass scale propagation and conservation of rare, endangered and threatened orchids.

Micropropagation of plants through in vitro methods has become a significant and informative technique to reproduce and make the availability of crops, orchids and ornamental plants that are otherwise difficult to propagate. Commercial orchids are predominantly produced by tissue culture and this technique is used routinely in many countries for mass scale production of orchid plants. Establishment of a reliable cloning methodology for this orchid is important in terms of enabling the rapid propagation and production of a large number of high quality plants. Thus, the present study was taken up to optimize the physical and chemical conditions for mass in vitro propagation of Dendrobium Red Bull through shoot tip culture.

\section{Materials and Methods}

The experiment was conducted at Plant Breeding and Biotechnology Laboratory and Green House of Agrotechnology Discipline, Khulna University, Khulna. The experiment was laid out according to CRD with 3 replications and 15 treatments. The matured Dendrobium Red Bull plants were collected from Dipto Orchid Nursery, Valuka, Mymensingh and were established in a nethouse. Newly grown shoot buds (keikies) of about $1.0-1.5 \mathrm{~cm}$ long were excised from mother plants. The collected keikies were washed with running tap water for three times and then treated with $70 \%$ ethanol for $60 \mathrm{sec}$ followed by treatment with $0.1 \%$ $\mathrm{NaOCl}$ solution for $8 \mathrm{~min}$. The treated keikies were again washed with double distilled water. The surface sterilized explants were then cultured on agarified MS supplemented with different combinations and concentrations of BAP and 
NAA for in vitro multiple shoot production. The cultures were subjected for five successive subcultures. For rooting, the in vitro grown shoots were cultured on agarified MS fortified with $2.0 \mathrm{mg} \Lambda$ IBA. The $\mathrm{pH}$ of the medium was adjusted to 5.8. The cultures were kept at $25 \pm 1^{\circ} \mathrm{C}$ and $65 \% \mathrm{RH}$ under $16 \mathrm{hrs}$ photoperiod at 3000 lux. The regenerated plants with about 3 - 4 roots were then transferred to ex vitro small pots containing four different substrates viz. fine sand, course sand, cocodust and brick gravels after removal of agar attached with the roots and treated with antifugal solution Bavistin@ $0.1 \%$. The pots were then covered with polythene after spraying water inside it and closed to check evapotranspiration and were kept in greenhouse for 7 days. Afterword the polythene were removed and the plantlets were kept in nethouse. Data were collected on in vitro and ex vitro parameters were analyzed for ANOVA. The differences between treatment means were compared by DMRT.

\section{Results and Discussion}

Newly grown shoot tips were used for shoot initiation and multiplication. Multiple shoots were observed without any intervening callus and protocormlike-body (PLB) formation. The efficacy of multiple shoot formation differed with concentrations and combinations of BAP and NAA (Table 1). After 60 days the plants started producing multiple shoots which varied from 1.00 to 2.00 shoots/plant. The treatment combination $3.0 \mathrm{mg} / \mathrm{l}$ BAP and $1.0 \mathrm{mg} / \mathrm{l} \mathrm{NAA}$ produced maximum number of shoots (3.33, 5.33 and 7.66, respectively). Minimum number of shoots were observed in the combination $1.00 \mathrm{mg} / \mathrm{l} \mathrm{BAP}$ and $0.5 \mathrm{mg} / \mathrm{l} \mathrm{NAA}$ at 90,120 and 150 days of culture $(1.33,1.66$ and 1.66 , respectively).

Paudel et al. (2012) found that multiple shoot development from shoot tip section was significantly promoted by concentrations of BAP $(0.5-2.0 \mathrm{mg} \Lambda)$ in combination with NAA $(0.5 \mathrm{mg} \Lambda)$. Pant and Thapa (2012) reported the maximum number of rootless healthy shoots (4.5/culture) on MS fortified with BAP (1.5 $\mathrm{mg} \Lambda)$ and NAA $(0.5 \mathrm{mg} \Lambda)$.

Length of in vitro grown shoots of Dendrobium varied significantly with varying concentrations and combinations of growth regulators (Table 2). At each stage of culture, maximum shoot lengths were recorded from the medium supplemented with $3.0 \mathrm{mg} / \mathrm{BAP}$ and $1.5 \mathrm{mg} / \mathrm{l} \mathrm{NAA}$ followed by the combination of $3.0 \mathrm{mg} / \mathrm{BAP}$ and $1.0 \mathrm{mg} / \mathrm{l} \mathrm{NAA}$. The regeneration media containing $1.0 \mathrm{mg} / \mathrm{l}$ $\mathrm{BAP}$ and $0.5 \mathrm{mg} / \mathrm{l}$ NAA produced the shortest shoot at every stages of culture.

Similar results were reported by Talukder et al. (2014) and observed the highest plant length $(0.252 \mathrm{~cm})$ on MS supplemented with $2.5 \mathrm{mg} / \mathrm{l}$ BAP along with $0.5 \mathrm{mg} / \mathrm{l} \mathrm{NAA}$. Bhattacharjee and Islam (2014) found that the combination of 
$1.0 \mathrm{mg} / \mathrm{l} \mathrm{NAA}$ and $1.0 \mathrm{mg} / \mathrm{l} \mathrm{BAP}$ as the best formulation for maximum shoot length $(4.0 \mathrm{~cm})$ of orchid in vitro.

Table 1. In vitro shoot production of Dendrobium Red Bull in varying levels of growth regulators.

\begin{tabular}{|c|c|c|c|c|c|}
\hline \multicolumn{2}{|c|}{ Growth regulators $(\mathrm{mg} / \mathrm{l})$} & \multicolumn{4}{|c|}{ Shoot no. at (DAC) } \\
\hline BAP & NAA & 60 & 90 & 120 & 150 \\
\hline 1 & 0.5 & 1.00 & $1.33 b$ & $1.66 \mathrm{f}$ & $1.66 \mathrm{e}$ \\
\hline 1 & 1.0 & 1.66 & $2.66 \mathrm{ab}$ & $3.66 \mathrm{bcd}$ & $5.00 \mathrm{bc}$ \\
\hline 1 & 1.5 & 1.33 & $1.66 \mathrm{~b}$ & $2.00 \mathrm{ef}$ & 2.66de \\
\hline 2 & 0.5 & 1.00 & $1.66 \mathrm{~b}$ & 2.66def & 2.66de \\
\hline 2 & 1.0 & 1.33 & $2.66 \mathrm{ab}$ & $4.00 \mathrm{bc}$ & $6.00 \mathrm{~b}$ \\
\hline 2 & 1.5 & 1.33 & $2.00 \mathrm{ab}$ & $2.33 \mathrm{ef}$ & $2.66 \mathrm{de}$ \\
\hline 3 & 0.5 & 1.33 & $2.00 \mathrm{ab}$ & $3.00 \mathrm{cde}$ & $4.00 \mathrm{~cd}$ \\
\hline 3 & 1.0 & 2.00 & $3.33 \mathrm{a}$ & $5.33 \mathrm{a}$ & $7.66 \mathrm{a}$ \\
\hline 3 & 1.5 & 1.33 & $2.33 \mathrm{ab}$ & $3.66 \mathrm{bcd}$ & $5.00 \mathrm{bc}$ \\
\hline 4 & 0.5 & 1.00 & $2.00 \mathrm{ab}$ & 2.66def & $4.66 b c$ \\
\hline 4 & 1.0 & 1.66 & $2.66 \mathrm{ab}$ & $4.33 \mathrm{ab}$ & $6.00 \mathrm{~b}$ \\
\hline 4 & 1.5 & 1.00 & $1.33 b$ & $2.33 \mathrm{ef}$ & 3.00de \\
\hline 5 & 0.5 & 1.33 & $1.66 \mathrm{~b}$ & 2.66def & $4.00 \mathrm{~cd}$ \\
\hline 5 & 1.0 & 1.33 & $2.33 \mathrm{ab}$ & $3.000 \mathrm{cde}$ & $4.00 \mathrm{~cd}$ \\
\hline 5 & 1.5 & 1.33 & $1.66 \mathrm{~b}$ & 2.66def & $3.000 \mathrm{de}$ \\
\hline \multicolumn{2}{|c|}{ Level of significance } & NS & * & $* *$ & $* *$ \\
\hline \multicolumn{2}{|l|}{ LSD } & & 1.207 & 1.067 & 1.232 \\
\hline \multicolumn{2}{|l|}{ CV (\%) } & 36.23 & 32.98 & 19.87 & 17.03 \\
\hline
\end{tabular}

DAC $=$ Days after culture, NS $=$ Not significant $(p>0.05),{ }^{*}=$ Significant at $p \leq 0.05$, ** $=$ Significant at $\leq 0.01$.

Due to the different combinations and concentrations of growth regulators significant variation was observed in leaf numbers also (Table 3). After 30 days of culture the shoots started to produce leaf and maximum (3.00) number of leaves was found in treatment $3.0 \mathrm{mg} / \mathrm{l} \mathrm{BAP}+1.5 \mathrm{mg} / \mathrm{l} \mathrm{NAA}$ whereas at 60 days of culture maximum number of leaves (5.33) were obtained from the treatment $3.0 \mathrm{mg} / \mathrm{l} \mathrm{BAP}+1.0 \mathrm{mg} / \mathrm{l} \mathrm{NAA}$. Later, at 90 days of culture, maximum leaf number (7.33) was recorded from the media containing $3.0 \mathrm{mg} / \mathrm{l} \mathrm{BAP}+1.0 \mathrm{mg} / \mathrm{l} \mathrm{NAA}$ and $2.0 \mathrm{mg} / \mathrm{l} \mathrm{BAP}+1.5 \mathrm{mg} / \mathrm{l} \mathrm{NAA}$ as well as $3.0 \mathrm{BAP} \mathrm{mg} / \mathrm{l}+1.5 \mathrm{mg} / \mathrm{l} \mathrm{NAA}$. At 120 $\mathrm{DAC}$, the maximum leaf (11.33) was found in combination of $3.0 \mathrm{mg} / \mathrm{l} \mathrm{BAP}+1.5$ $\mathrm{mg} / \mathrm{l}$ NAA. Finally, at $150 \mathrm{DAC}$, the medium supplemented with $3.0 \mathrm{mg} / \mathrm{l} \mathrm{BAP}+$ $1.0 \mathrm{mg} / \mathrm{l} \mathrm{NAA}$ and $3.0 \mathrm{mg} / \mathrm{BAP}+1.5 \mathrm{mg} / \mathrm{l}$ produced maximum number of leaves (13.33) followed by the medium having $2.0 \mathrm{mg} / \mathrm{l} \mathrm{BAP}+1.0 \mathrm{mg} / \mathrm{l} \mathrm{NAA}$ (11.3). 
Kabir and Al-amin (2010) found the highest leaf number from $1.0 \mathrm{mg} / \mathrm{l}$ of each BAP and NAA and the lowest from $0.5 \mathrm{mg} / \mathrm{l}$ each of BAP and NAA. Nasiruddin et al. (2003) found maximum number of leaves (4.42) per shoot at $2.5 \mathrm{mg} / \mathrm{l} \mathrm{BAP}$.

Table 2. Length of in vitro produced shoot at different DAC of Dendrobium Red Bull.

\begin{tabular}{|c|c|c|c|c|c|c|}
\hline \multicolumn{3}{|c|}{ Growth regulators $(\mathrm{mg} / \mathrm{l})$} & \multicolumn{4}{|c|}{ Shoot length $(\mathrm{mm})$ at (DAC) } \\
\hline BAP & NAA & 30 & 60 & 90 & 120 & 150 \\
\hline 1 & 0.5 & $5.39 \mathrm{~g}$ & $6.79 \mathrm{ef}$ & $7.75 \mathrm{i}$ & $9.11 \mathrm{~g}$ & 12.24efgh \\
\hline 1 & 1.0 & 5.97efg & 7.19def & 8.37hi & 10.04defg & $11.44 \mathrm{fgh}$ \\
\hline 1 & 1.5 & $6.85 \mathrm{cde}$ & $8.99 \mathrm{c}$ & 11.62cde & $12.68 \mathrm{bc}$ & $14.46 \mathrm{~cd}$ \\
\hline 2 & 0.5 & 6.05 efg & $6.98 \mathrm{ef}$ & 8.35hi & $9.36 f g$ & 10.90fgh \\
\hline 2 & 1.0 & $5.66 \mathrm{fg}$ & $6.55 f$ & $7.99 \mathrm{i}$ & $9.46 f g$ & $11.45 \mathrm{fgh}$ \\
\hline 2 & 1.5 & $7.55 \mathrm{bc}$ & $10.72 \mathrm{ab}$ & $12.68 \mathrm{bc}$ & $16.30 \mathrm{a}$ & $17.26 \mathrm{~b}$ \\
\hline 3 & 0.5 & $5.98 \mathrm{efg}$ & 7.02ef & 8.38hi & 9.56efg & $10.43 \mathrm{~h}$ \\
\hline 3 & 1.0 & $7.84 \mathrm{~b}$ & $10.89 a$ & $13.86 \mathrm{ab}$ & $16.65 a$ & $20.98 a$ \\
\hline 3 & 1.5 & $8.86 \mathrm{a}$ & $12.06 a$ & $15.13 a$ & $18.05 a$ & $21.19 a$ \\
\hline 4 & 0.5 & 6.43def & 8.36cde & 9.98efgh & $11.67 \mathrm{cdef}$ & 13.69de \\
\hline 4 & 1.0 & $7.01 \mathrm{bcd}$ & $8.79 \mathrm{~cd}$ & 10.48defg & $11.95 \mathrm{bcde}$ & $12.49 \mathrm{efg}$ \\
\hline 4 & 1.5 & $7.05 \mathrm{bcd}$ & $9.30 \mathrm{bc}$ & $11.85 \mathrm{~cd}$ & $14.11 b$ & $15.60 \mathrm{bc}$ \\
\hline 5 & 0.5 & $7.13 \mathrm{bcd}$ & $8.32 \mathrm{cde}$ & 9.54fghi & 10.99cdefg & 11.89efgh \\
\hline 5 & 1.0 & $7.18 \mathrm{bcd}$ & $7.80 \mathrm{cdef}$ & 8.85ghi & 9.80defg & $10.56 \mathrm{gh}$ \\
\hline 5 & 1.5 & 6.52def & $8.34 \mathrm{cde}$ & 10.84def & $12.17 \mathrm{bcd}$ & $12.82 \mathrm{def}$ \\
\hline \multicolumn{2}{|c|}{ Level of significance } & ** & ** & $* *$ & $* *$ & $* *$ \\
\hline \multicolumn{2}{|l|}{ LSD } & 0.8615 & 1.501 & 1.640 & 2.161 & 1.793 \\
\hline \multicolumn{2}{|l|}{ CV (\%) } & 7.27 & 10.04 & 9.02 & 10.17 & 7.40 \\
\hline
\end{tabular}

DAC $=$ Days after culture, ${ }^{* *}=$ Significant at $\mathrm{p} \leq 0.01$.

The in vitro grown shoots of orchid were cultured in root inducing medium and effect of initial shoot inducing medium was observed on root induction (Table 4). Root number varied from 2.33 to 4.67 . The shoot obtained from the cultures containing $4.0 \mathrm{mg} / \mathrm{l} \mathrm{BAP}$ and $1.5 \mathrm{mg} / \mathrm{l} \mathrm{NAA}$ produced maximum number of roots (4.67). The shoots from media having $1.0 \mathrm{mg} / \mathrm{l} \mathrm{BAP}+1.0 \mathrm{mg} / \mathrm{l} \mathrm{NAA}, 1.0$ $\mathrm{mg} / \mathrm{l} \mathrm{BAP}+1.5 \mathrm{mg} / \mathrm{l} \mathrm{NAA}, 2.0 \mathrm{mg} / \mathrm{l} \mathrm{BAP}+0.5 \mathrm{mg} / \mathrm{l} \mathrm{NAA}$ and $2.0 \mathrm{mg} / \mathrm{l} \mathrm{BAP}+1.0$ $\mathrm{mg} / \mathrm{l}$ NAA produced least number of roots (3.00) in root induction media.

Paudel and Pant (2012) found a maximum number of roots $(3.0 \pm 0.40)$ on NAA $(0.5 \mathrm{mg} / \mathrm{l})$ and higher concentration of NAA showed the poor result of rooting in Dendrobium. Wang (2015) reported the higher number (4.6) of roots of Dendrobium from the medium containing $0.5 \mathrm{mg} / \mathrm{l} \mathrm{BAP}$ and $2.0 \mathrm{mg} / \mathrm{l}$ NAA. 
Ex vitro survivability of in vitro grown plantlets is a crucial aspect of in vitro propagation. A substantial number of micropropagated plants do not survive when transferred from in vitro conditions to greenhouse or field environment. In this study, the survivability of plantlets on different substrates viz. fine sand, course sand, cocodust and bricks gravels showed variable results (Fig. 1). The $e x$ vitro survivability of the plantlets varied from 60 to $92 \%$. The maximum survivability (92\%) was observed on cocodust and that of minimum $(60 \%)$ from substrate containing course sand.

Table 3. Leaf production efficiency of in vitro grown shoot tips of Dendrobium Red Bull.

\begin{tabular}{|c|c|c|c|c|c|c|}
\hline \multicolumn{2}{|c|}{$\begin{array}{l}\text { Growth regulators } \\
\qquad(\mathrm{mg} \Lambda)\end{array}$} & \multicolumn{5}{|c|}{ Leaf number at (DAC) } \\
\hline BAP & NAA & 30 & 60 & 90 & 120 & 150 \\
\hline 1 & 0.5 & 2.33 & $3.33 b c$ & $5.00 \mathrm{bc}$ & $6.00 \mathrm{~d}$ & $6.66 \mathrm{~d}$ \\
\hline 1 & 1.0 & 2.33 & $3.66 \mathrm{bc}$ & $5.00 \mathrm{bc}$ & $6.66 \mathrm{~d}$ & $8.00 \mathrm{~cd}$ \\
\hline 1 & 1.5 & 2.33 & $3.33 c$ & $5.00 \mathrm{bc}$ & $6.33 d$ & $8.00 \mathrm{~cd}$ \\
\hline 2 & 0.5 & 2.00 & $3.00 \mathrm{c}$ & $3.66 c$ & $6.66 \mathrm{~d}$ & $8.66 \mathrm{bcd}$ \\
\hline 2 & 1.0 & 2.00 & $2.66 \mathrm{c}$ & $5.33 \mathrm{abc}$ & $7.33 \mathrm{~cd}$ & $9.66 \mathrm{bc}$ \\
\hline 2 & 1.5 & 3.00 & $5.00 \mathrm{a}$ & $7.33 a$ & $9.66 \mathrm{abc}$ & 11.33ab \\
\hline 3 & 0.5 & 2.33 & $3.66 \mathrm{bc}$ & $5.66 \mathrm{abc}$ & $7.33 \mathrm{~cd}$ & $9.33 \mathrm{bcd}$ \\
\hline 3 & 1.0 & 2.66 & $5.33 a$ & $7.33 a$ & $10.33 \mathrm{ab}$ & $13.33 \mathrm{a}$ \\
\hline 3 & 1.5 & 3.00 & $4.66 \mathrm{ab}$ & $7.33 a$ & $11.33 a$ & $13.33 a$ \\
\hline 4 & 0.5 & 2.00 & $2.66 \mathrm{c}$ & $4.66 \mathrm{bc}$ & $6.66 \mathrm{~d}$ & $9.33 \mathrm{bcd}$ \\
\hline 4 & 1.0 & 2.33 & $3.66 \mathrm{bc}$ & $5.33 \mathrm{abc}$ & $6.66 \mathrm{~d}$ & $8.00 \mathrm{~cd}$ \\
\hline 4 & 1.5 & 2.66 & $3.66 \mathrm{bc}$ & $6.00 \mathrm{ab}$ & $8.33 \mathrm{bcd}$ & $9.66 \mathrm{bc}$ \\
\hline 5 & 0.5 & 2.00 & $3.33 c$ & $5.33 \mathrm{abc}$ & $6.66 \mathrm{~d}$ & $8.33 \mathrm{~cd}$ \\
\hline 5 & 1.0 & 2.00 & $3.00 \mathrm{c}$ & $5.00 \mathrm{bc}$ & $7.00 \mathrm{~d}$ & $9.33 \mathrm{bcd}$ \\
\hline 5 & 1.5 & 2.33 & $3.66 \mathrm{bc}$ & $6.00 \mathrm{ab}$ & $7.66 \mathrm{~cd}$ & $10.33 b c$ \\
\hline \multicolumn{2}{|c|}{ Level of significance } & NS & $* *$ & $* *$ & $* *$ & ** \\
\hline \multicolumn{2}{|l|}{ LSD } & & 1.176 & 1.880 & 2.161 & 2.362 \\
\hline \multicolumn{2}{|l|}{ CV $(\%)$} & 17.98 & 18.42 & 19.17 & 16.90 & 14.78 \\
\hline
\end{tabular}

DAC $=$ Days after culture, NS $=$ Not significant $(p>0.05),{ }^{*}=$ Significant at $p \leq 0.05$, ** $=$ Significant at $\leq 0.01$.

Rao and Barman (2014) reported 88\% survivability of in vitro grown shoots of orchid when they were transferred to sterile mixture of brick and charcoal and vermicompost. Rahman et al. (2009) reported that well rooted micropropagated plantlets were hardened successfully in the potting mixture containing coconut husk, charcoal and brick pieces in the ratio of $2: 1: 1$. 
Table 4. Root induction efficiency of grown shoots of Dendrobium Red Bull in vitro.

\begin{tabular}{|c|c|c|c|}
\hline \multirow{2}{*}{ Media } & \multicolumn{2}{|c|}{ Growth regulators } & \multirow{2}{*}{ Root number } \\
\hline & BAP & NAA & \\
\hline MS & 1 & 0.5 & 3.33 \\
\hline MS & 1 & 1.0 & 3.00 \\
\hline MS & 1 & 1.5 & 3.00 \\
\hline MS & 2 & 0.5 & 3.00 \\
\hline MS & 2 & 1.0 & 3.00 \\
\hline MS & 2 & 1.5 & 4.00 \\
\hline MS & 3 & 0.5 & 3.66 \\
\hline MS & 3 & 1.0 & 2.33 \\
\hline MS & 3 & 1.5 & 3.33 \\
\hline MS & 4 & 0.5 & 2.66 \\
\hline MS & 4 & 1.0 & 3.33 \\
\hline MS & 4 & 1.5 & 4.67 \\
\hline MS & 5 & 0.5 & 4.00 \\
\hline MS & 5 & 1.0 & 4.00 \\
\hline MS & 5 & 1.5 & 2.67 \\
\hline Level of significance & & & NS \\
\hline CV $(\%)$ & & & $44.79 \%$ \\
\hline
\end{tabular}

NS $=$ Not significant $(\mathrm{p}>0.05)$.

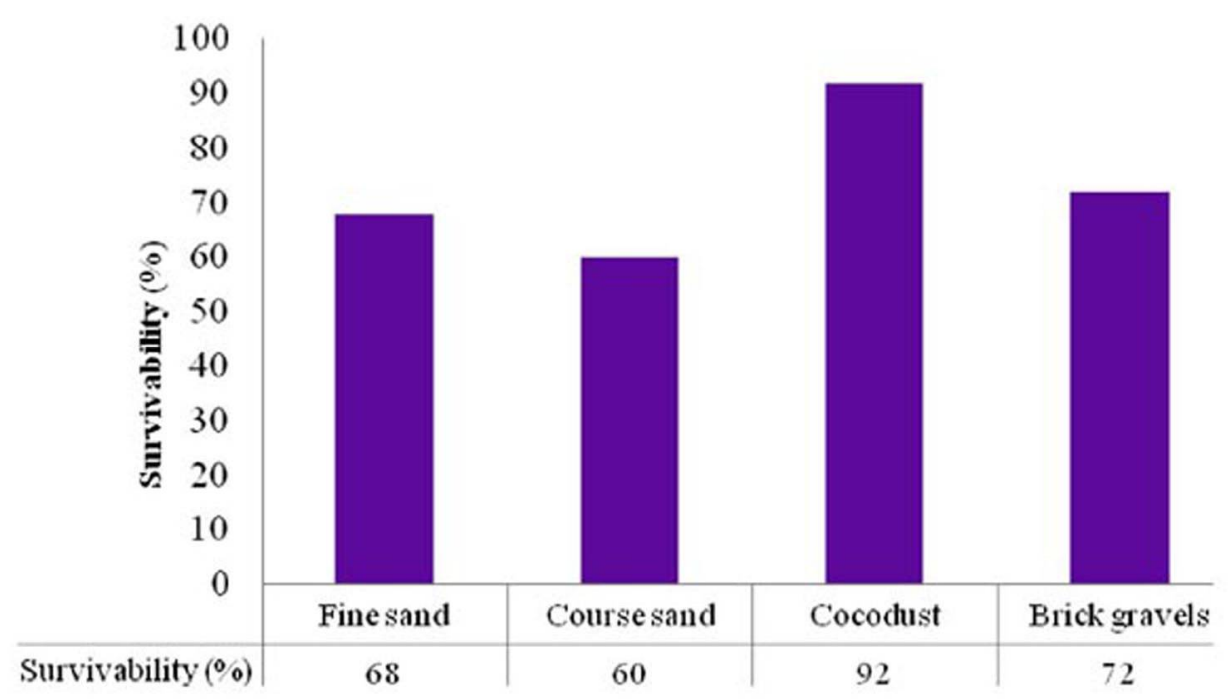

Fig. 1. Diagrammatic representation of ex vitro survivability rate of in vitro grown orchid. 

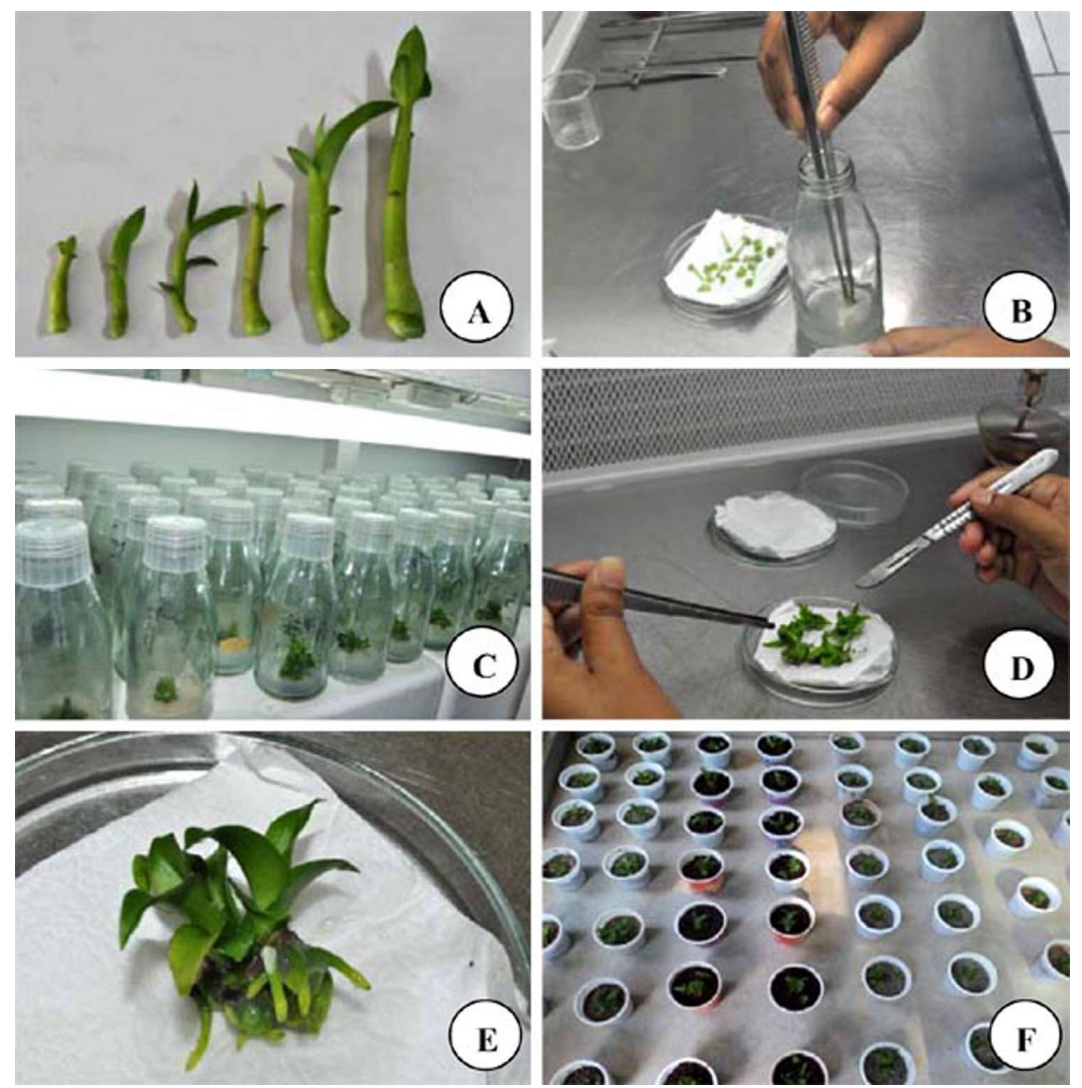

Fig. 2. Different stages of in vitro micropropagation of Dendrobium on growth regulators supplemented MS. A. Excised shoots. B. Culturing of shoot tip for multiplication. C. Multiple shoots in vitro. D. Multiple shoots culturing for rooting. E. Well rooted plantlets. F. Ex vitro transferred hardened plants.

In in vitro micropropagation of Dendrobium Red Bull, maximum shoots were obtained from $3.0 \mathrm{mg} / \mathrm{l} \mathrm{BAP}+1.0 \mathrm{mg} / \mathrm{l}$ NAA. The highest shoot length as well as number of leaves were recorded from $3.0 \mathrm{mg} / \mathrm{l} \mathrm{BAP}+1.5 \mathrm{mg} / \mathrm{l} \mathrm{NAA}$ and $3 . \mathrm{mg} / \mathrm{l}$ $\mathrm{BAP}+1.0 \mathrm{mg} / \mathrm{l} \mathrm{NAA}$. The maximum root numbers were observed for the shoots obtained from $4.0 \mathrm{mg} / \mathrm{l} \mathrm{BAP}+1.0 \mathrm{mg} / \mathrm{l} \mathrm{NAA}$. In the present study, the best combination was $3.0 \mathrm{mg} / \mathrm{l} \mathrm{BAP}+1.0 \mathrm{mg} / \mathrm{l} \mathrm{NAA}$ and $3.0 \mathrm{mg} / \mathrm{l} \mathrm{BAP}+1.5 \mathrm{mg} / \mathrm{l} \mathrm{NAA}$ for shoot production, shoot length and leaf numbers.

\section{Acknowledgement}

The authors are grateful to Khulna University Research Cell, Khulna University, Khulna-9208, Bangladesh for financial assistance under Research Grants Program (RGP) to carry out the research work. 


\section{References}

Arditti J, Clement MA, Fast G, Hadley G, Nishimura G and Ernest R (1982) Orchid seed and Perspectives II. Cornel University Press, Itacea and London.

Bhattacharjee B and Islam SM (2014) Effects of plant growth regulators on multiple shoot induction in Vanda tessellata (Roxb.) Hook. an endangered medicinal orchid. Int. J. Sci. Nat. 5: 707-712.

Chen QX and Ji ZH (1998) Encyclopedia of China orchid. Beijing, China. China Forestry Publishing House, China.

Chen XM and Guo SX (2003) Advances in research of constituents and pharmacology of Dendrobium. Nat. Pro. Res. and Dev. 13: 70-75.

Kabir H and Al-amin S (2010) Direct shoot regeneration from nodes of Phalaenopsis orchids. Acta Agric Slov. 2: 233-234.

Nasiruddin KM, Begum R and Yasmin S (2003) Protocorm like bodies and plant regeneration from Dendrobium formosum lead callus. Asian J. Plant Sci. 2: 955-957.

Pant B and Thapa D (2012) In vitro mass propagation of an epiphytic orchid Dendrobium primulinum Lindl. through shoot tip culture. African J. of Biotech. 11: 9970-9974.

Paudel MR and Pant B (2012) In vitro micro propagation of rare orchid (Esmeralda clarkei Rchb.f.) from shoot tip culture. Int. J. of Biol. Pharm and Allied Sci. 1: 1587-1597.

Rahman MS, Hasan MF, Das R, Hossain MS and Rahman M (2009) In vitro micropropagation of orchid (Vanda tessellata L.) from shoot tip explants. J. Bio-Sci. 17: 139-144.

Rao AN (1997) Tissue culture in Orchid Industry. In: Reinert J and Bajaj YPS (Edt.), Applied and Fundamental aspects of Plant Cell, Tissue and Organ Culture, Narosa publ. House, New Delhi, pp. 46-69.

Rao S and Barman B (2014) In vitro micro propagation of Dendrobium chrysanthum Wall. Ex Lindl. A threatened orchid. Sch Acad J. Biosci. 2: 39-42.

Talukder SK, Nasiruddin KM, Yasmin S, Begum R and Sarker S (2014) In vitro root formation on orchid plantlets with IBA and NAA. Progress Agric. 13: 25-28.

Wang (2015) Tissue culture of Dendrobium: Plant and flower induction in vitro. Lindleyana 5: $130-145$.

Zhang M, Xia HX, Zhu LQ and Zhang YJ (2000) Advances in studies on tissue culture of Dendrobium Sw. China J. Chinese Mat. Med. 25: 323-326. 